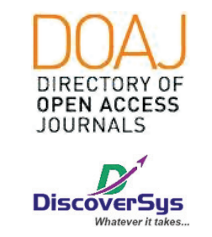

Published by DiscoverSys

\section{Pola sidik jari (Dermatoglifi) sebagai metode skrining diagnostik Sindrom Down pada anak}

\author{
I Made Adi Narendranatha Komara, ${ }^{1 *}$ I Putu Oka Kresna Jayadi, ${ }^{1}$ \\ I Gusti Ayu Gayatri Sidemen, ${ }^{1}$ Putu Triyasa, ${ }^{2}$ I Ketut Tangking Widiarsa, ${ }^{2}$ \\ Sagung Putri Permana Lestari Murdhana Putere ${ }^{3}$
}

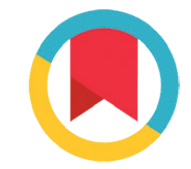

CrossMark

\title{
ABSTRACT
}

Background: Fluorescence in Situ Hybridization (FISH) or complete chromosomal examination (karyotyping) is an examination of the gold standard in the diagnosis of Down syndrome, but it is quite expensive, so not all people in the society can use it. The purpose of this study was to determine the differences between the mean frequency of dermatoglyphics occurrence patterns and to determine the level of sensitivity and specificity of dermatoglyphics diagnostic tests on people with Down Syndrome.

Methods: The method used in this study was observational analytic with a cross sectional study on 28 children who have Down syndrome derived from SLB C Negeri Tuna Grahita and 28 normal children of primary school 14 Dauh Puri. Data analysis using Independent T-test, a diagnostic test with sensitivity and specificity parameters was conducted by Receiver Operating Characteristic (ROC) curve. Data were analyzed using SPSS version 17 for Windows.

Results: The results showed that on average, the highest percentage fingerprint patterns in people with Down syndrome are ulnar loops with a mean 6.39, whereas in normal children is a whorl with a mean 2.25. The diagnostic test, ulnar loop pattern, has the highest degree of accuracy with a cut-off $=4$ followed by sensitivity value 1 ( 0.87 to 1$)$ and a specificity 1 ( 0.87 to 1$)$.

Conclusion: There are differences in the frequency of occurrence of fingerprint patterns in children with Down syndrome and normal children, as well as the patterns of the ulnar loop has the highest accuracy rate of sensitivity and specificity of the diagnostic test.

Keywords: Dermatoglyphics, Down Syndrome, Ulnar Loop, Screening Cite This Article: Komara, I.M.A.N., Jayadi, I.P.O.K., Sidemen, I.G.A.G., Triyasa, P., Widiarsa, I.K.T., Putere, S.P.P.L.M. 2020. Pola sidik jari (Dermatoglifi) sebagai metode skrining diagnostik Sindrom Down pada anak. Intisari Sains Medis 11(2): 601-605. D0I: 10.15562/ism.v11i2.610

\section{ABSTRAK}

'Departemen IImu Kesehatan Anak, Fakultas Kedokteran dan IImu Kesehatan, Universitas Warmadewa, Rumah Sakit Umum Daerah (RSUD) Sanjiwani, Bali, Indonesia

${ }^{2}$ Dosen Bagian IKK-IKP, Fakultas Kedokteran dan IImu Kesehatan, Universitas Warmadewa, Bali, Indonesia

${ }^{3}$ Dosen Bagian Medical Education Unit (MEU), Fakultas Kedokteran dan IImu Kesehatan, Universitas Warmadewa, Bali, Indonesia

*Korespondensi:

I Made Adi Narendranatha Komara, Departemen IImu Kesehatan Anak, Fakultas Kedokteran dan IImu

Kesehatan, Universitas Warmadewa, Rumah Sakit Umum Daerah (RSUD) Sanjiwani, Bali, Indonesia

adinarendra40@gmail.com

Diterima: 06-09-2019

Disetujui: 22-05-2020

Diterbitkan: 01-08-2020
Latar Belakang: Fluorescence in Situ Hybridization (FISH) atau pemeriksaan kromosom lengkap (kariotyping) merupakan pemeriksaan baku emas dalam penegakan diagnosis sindrom Down, namun tergolong mahal sehingga tidak semua lapisan masyarakat mampu menggunakannya. Tujuan penelitian ini adalah untuk mengetahui perbedaan rerata frekuensi kemunculan pola dermatoglifi serta untuk mengetahui tingkat sensitivitas dan spesifisitas uji diagnostik dermatoglifi terhadap penderita sindrom Down.

Metode: Metode yang digunakan pada penelitian ini adalah observasi analitik dengan studi potong lintang terhadap 28 anak yang mengalami sindrom Down didapat dari SLB C Negeri Tuna Grahita dan 28 anak normal dari SD Negeri 14 Dauh Puri. Analisis data menggunakan uji analisis $T$ tidak berpasangan dan uji diagnostik dengan parameter sensitivitas dan spesifisitas menggunakan Reciever Operating Characteristic (ROC). Data dianalisis dengan SPSS versi 17 untuk Windows.

Hasil: Hasil penelitian menunjukkan bahwa rata-rata persentase tertinggi pola sidik jari pada penderita sindrom Down adalah loop ulnar dengan nilai mean 6,39, sedangkan pada anak normal adalah whorl dengan nilai mean 2,25. Dalam uji diagnostik, pola loop ulnar memiliki tingkat akurasi tertinggi dengan cut off $=4$ diikuti nilai sensitivitas 1 (0,87-1) dan spesifisitas $1(0,87-1)$.

Kesimpulan: Terdapat perbedaan frekuensi kemunculan pola sidik jari pada anak dengan sindrom Down dan anak normal, serta pola loop ulnar memiliki tingkat akurasi sensitivitas dan spesifisitas tertinggi dalam uji diagnostik.

Kata kunci: Dermatoglifi, Sindrom Down, Loop Ulnar, Skrining

Cite Pasal Ini: Komara, I.M.A.N., Jayadi, I.P.O.K., Sidemen, I.G.A.G., Triyasa, P., Widiarsa, I.K.T., Putere, S.P.P.L.M. 2020. Pola sidik jari (Dermatoglifi) sebagai metode skrining diagnostik Sindrom Down pada anak. Intisari Sains Medis 11(2): 601-605. D0I: 10.15562/ism.v11i2.610

\section{PENDAHULUAN}

Sindrom Down merupakan kelainan genetik yang terjadi karena kelebihan jumlah kromosom akibat kegagalan pemisahan kromosom (non disjunction) pada saat proliferasi sel. ${ }^{1}$ sindrom Down merupakan kelainan kromosom yang paling sering dijumpai pada anak-anak di negara maju maupun 
berkembang. ${ }^{2}$ Jumlah penderita sindrom Down di dunia berkisar 8 juta pada tahun 2014 dan diestimasi akan meningkat sekitar 5 ribu penderita tiap tahunnya. ${ }^{1,2}$ Riset Kesehatan Dasar (RISKESDAS) tahun 2013 menyebutkan di Indonesia terdapat 300 ribu anak yang menderita Sindrom Down. ${ }^{3}$

Penderita sindrom Down atau Trisomi 21 adalah pasien yang memiliki kromosom 21 berjumlah 3. ${ }^{1,2}$ Pada beberapa kasus, kejadian sindrom Down juga erat kaitannya dengan mutasi pada lokus 21q22.13-q22.2 dengan besaran 4,3-5Mb dimana terdapat lokasi gen yang berhubungan dengan gejala klinik penderita. ${ }^{4,5}$ Sindrom Down dapat dideteksi melalui metode Fluorescence in Situ Hybridization (FISH) atau pemeriksaan kromosom lengkap (kariotyping). ${ }^{6,7}$ Meskipun kedua pemeriksaan tersebut memiliki spesifisitas dan sensitivitas yang tinggi, namun pemeriksaan tersebut tergolong mahal dan akan sangat merugikan apabila penderita didiagnosis positif atau negatif palsu pada pemeriksaan klinis. ${ }^{6,7}$

Dermatoglifi atau pola sidik jari adalah gambaran sulur-sulur dermal yang pararel pada jari-jari tangan dan kaki, serta telapak tangan dan telapak kaki. ${ }^{8}$ Pihak kepolisian dan kedokteran kehakiman telah sejak lama menggunakan pola sidik jari sebagai alat identifikasi korban maupun pelaku kriminalitas. ${ }^{8}$ Gambaran sidik jari ini merupakan suatu manifestasi genetik yang dikendalikan oleh banyak gen (polygenic) dimana pola dasarnya tidak akan berubah sepanjang hayat.' Pembentukan pola sidik jari yang sangat dipengaruhi oleh faktor genetik mendorong para ilmuan mengembangkan metode dermatoglifi sebagai alat untuk mendeteksi dini penyakit genetik. Studi yang dilakukan Palomaki GE pada tahun 2011 menyebutkan bahwa penderita kelainan genetik antara lain sindrom Down, Sindrom Turner, Sindrom Klinefelter, dan Sindrom Edward, memiliki sulur ujung jari tangan (sidik jari) yang khas. ${ }^{10}$

Pemeriksaan dermatoglifi mampu membedakan 4 tipe pola sidik jari utama (loop ulna, loop radial, whorl, dan arch). ${ }^{8}$ Studi yang dilakukan Masni $\mathrm{R}$ et al., melakukan penelitian tentang pola sidik jari pada penderita hemophilia dan orang normal di Sumatra Barat pada tahun 2014. ${ }^{11}$ Hasil penelitian tersebut menunjukkan bahwa terdapat perbedaan yang signifikan pada pola loop radial sebesar $(33 \%>28,5 \%)$ dibandingkan dengan orang normal. ${ }^{11}$ Penelitian yang dilakukan oleh Irawan R et al., pada tahun 2010 juga menunjukkan terdapat perbedaan pola sidik jari diantaranya loop ulnar $(63,4 \%)$, whorl $(37,1 \%)$ dan jumlah sulur $(144,1)$ lebih tinggi dibandingkan anak normal. ${ }^{12}$

Dewasa ini, informasi tentang penderita sindrom Down di Kota Denpasar masih sangat kurang. Mengingat besarnya biaya yang dikeluarkan dalam pemeriksaan laboratorium FISH maupun kromosom lengkap, tidak semua lapisan masyarakat dapat melakukannya. Berkaitan dengan hal tersebut maka penelitian ini bertujuan untuk melakukan pemeriksaan dermatoglifi anak dengan sindrom Down di SLB C Negeri Tunagrahita dan anak normal di SD Negeri 14 Dauh Puri diharapkan dapat menjadi metode skrining alternatif uji diagnostik klinis dalam menegakkan dignosis penderita sindrom Down.

\section{METODE PENELITIAN}

Jenis penelitian ini bersifat observasional analitik dengan pendekatan potong lintang terhadap penderita sindrom Down yang didiagnosis secara klinis didapat dari SLB C Negeri Tunagrahita dan anak tanpa sindrom Down di SD Negeri 14 Dauh Puri dengan penentuan sampel secara acak (simple random sampling) melalui pengamatan pola sidik jari mereka. Terdapat total 56 anak terlibat sebagai responden pada penelitian ini.

Subjek penelitian terdiri dari 2 kelompok dimana masing-masing kelompok jumlahnya sama, yaitu 28 subjek penelitian untuk tiap kelompok anak dengan sindrom Down dan anak normal. Kriteria inklusi meliputi anak yang bersekolah di SLB C Negeri Tunagrahita yang memenuhi kriteria klinis penyakit sindrom Down serta anak normal di SD Negeri 14 Dauh Puri dalam rentang umur 6-12 tahun dan berjenis kelamin laki-laki serta perempuan. Kriteria eksklusi meliputi; terdapat cacat pada salah satu jari atau lebih yang dapat merusak pola sidik jari dan menolak untuk berpartisipasi dalam penelitian. Subjek penelitian dikatakan drop out apabila responden dalam masa cuti pada saat pengumpulan data.

Variabel bebas dalam penelitian ini meliputi anak penderita sindrom Down di SLB C Negeri Tuna Grahita dan anak normal di SD Negeri 14 Dauh Puri. Variabel tergantung meliputi pola sidik jari (loop ulna, loop radial, whorl, dan arch). Alat dan bahan yang digunakan dalam penelitian adalah tinta sampel merk ink berwarna ungu, kertas buffalo tipis berwarna putih, bak stempel, kaca pembesar, lap kering, dan sabun. Proses pengumpulan data dilakukan dengan prosedur teknis, diantaranya untuk mendapatkan gambaran pola sidik jari dari subjek penelitian dengan menempelkan kedua tangan yang telah dibubuhi tinta ungu (melalui bak stempel) pada kertas yang disediakan, kemudian gambar yang telah didapat, diamati langsung terhadap pola sidik jari (pola loop ulnar, loop radial, whorl, dan arch) pada penderita sindrom Down dan anak normal dengan bantuan kaca pembesar dibawah bimbingan dan bantuan dari pihak yang berkompeten dalam hal ini kepolisian dari Polresta 
Denpasar sektor kriminalitas. Gambar 1 menunjukkan 4 pola utama dermatoglifi (loop ulnar, loop radial, whorl, dan arch) yang akan dianalisis dalam penelitian.

Analisis data dilakukan dengan sistem komputerisasi. Analisis T tidak berpasangan (independent T-test) untuk menganalisis perbedaan frekuensi kemunculan pola dermatoglifi masing-masing tangan pada penderita sindrom Down di SLB C Negeri Tuna Grahita dan anak normal di SD Negeri 14 Dauh Puri. Analisis akurasi pola dermatoglifi sebagai alat skrining menggunakan metode analisis uji diagnostik dengan beberapa parameter; sensitivitas, spesifisitas, dan area dibawah curva Reciever Operating Characteristic (ROC). Data dianalisis dengan SPSS versi 17 untuk Windows.

\section{HASIL PENELITIAN}

Responden dalam penelitian ini berjumlah 56 orang yang meliputi 28 penderita sindrom Down dan 28 anak normal. Tabel 1 menunjukkan perolehan

Tabel 1 Karakteristik responden penelitian bedasarkan jenis kelamin

\begin{tabular}{lcc}
\hline Karakteristik & $\begin{array}{c}\text { Sindrom Down } \\
(\mathbf{n = 2 8})\end{array}$ & $\begin{array}{c}\text { Normal } \\
(\mathbf{n = 2 8})\end{array}$ \\
\hline $\begin{array}{l}\text { Jenis Kelamin, } \mathbf{n}(\%) \\
\text { Laki-laki }\end{array}$ & \\
Perempuan & $16(57,14)$ & $15(53,57)$ \\
\hline
\end{tabular}

Tabel 2 Perbedaan Rerata Frekuensi Kemunculan Pola Dermatoglifi

\begin{tabular}{lccc}
\hline & $\begin{array}{c}\text { Sindrom Down } \\
(\mathbf{n}=\mathbf{2 8}) \\
\text { Rerata (SD) }\end{array}$ & $\begin{array}{c}\text { Normal } \\
(\mathbf{n} 2=\mathbf{2 8}) \\
\text { Rerata (SD) }\end{array}$ & Nilai p \\
\hline Whorl & $2,25(0,64)$ & $4,82(0,61)$ & $0,000^{*}$ \\
Arch & $0,57(0,63)$ & $1,67(0,54)$ & $0,000^{*}$ \\
Loop Radial & $0,78(0,78)$ & $0,53(0,79)$ & $0,240^{*}$ \\
Loop Ulnar & $6,39(0,62)$ & $2,96(0,18)$ & $0,000^{*}$ \\
\hline
\end{tabular}

"Nilai P dikatakan bermakna apabila di bawah 0,05

Tabel 3 Hasil Uji Diagnostik Klinis

\begin{tabular}{lccc}
\hline Dermatoglifi & $\begin{array}{c}\text { Sensitivitas } \\
\mathbf{( 9 5 \% ~ I K ) ~}\end{array}$ & $\begin{array}{c}\text { Spesifisitas } \\
\mathbf{( 9 5 \% ~ I K ) ~}\end{array}$ & $\begin{array}{c}\text { ROC } \\
\mathbf{( 9 5 \% ~ I K ) ~}\end{array}$ \\
\hline Whorl (cut off = 2) & $0,89(0,7-0,9)$ & $0,00(0,0-0,1)$ & $0,45(0,3-0,5)$ \\
Arch (cut off =1) & $0,50(0,3-0,6)$ & $0,03(0,0-0,1)$ & $0,27(0,1-0,3)$ \\
Loop Radial (cut off =2) & $0,14(0,0-0,3)$ & $0,89(0,7-0,9)$ & $0,51(0,4-0,6)$ \\
Loop Ulnar (cut off =4) & $1,00(0,8-1,0)$ & $1,00(0,8-1,0)$ & $1,00(1,0-1,0)$ \\
\hline
\end{tabular}

Keterangan: cut off $1=$ dikatakan sebagai sindrom Down apabila ditemukan minimal pada 1 jari tangan, cut off $2=$ dikatakan sebagai sindrom Down apabila ditemukan minimal pada 2 jari tangan, cut off $3=$ dikatakan sebagai sindrom Down apabila ditemukan minimal pada 3 jari tangan, cut off $4=$ dikatakan sebagai sindrom Down apabila ditemukan minimal pada 4 jari tangan; IK: Interval Kepercayaan; ROC: Receiver Operating Curves subjek penelitian antara lain anak dengan sindrom Down laki-laki sebanyak 16 orang $(57,14 \%)$, anak dengan sindrom Down perempuan sebanyak 12 orang $(42,86 \%)$, sedangkan responden normal anak laki-laki sebanyak 15 orang $(53,57 \%)$ dan responden normal anak perempuan sebanyak 13 orang $(46,43 \%)$.

Dari Tabel 2 diperoleh informasi bahwa gambaran pola sidik jari penderita sindrom Down dan anak normal memiliki keempat tipe pola utama yaitu whorl, arch, loop radial, dan loop ulnar. Rerata frekuensi kemunculan pola tertinggi pada anak dengan sindrom Down adalah loop ulnar dengan nilai rerata 6,39 $(0,62)$ (Tabel 2). Terdapat perbedaan rerata dermatoglifi pada pasien sindrom Down maupun normal pada bentuk whorl, arch, dan loop ulnar ( $\mathrm{p}=0,000$ ) (Tabel 2).

Analisis uji diagnostik pola dermatoglifi dalam penelitian ini dilakukan dengan beberapa parameter diantaranya; sensitivitas, spesifisitas, dan area dibawah curva ROC. Berdasarkan analisis, pola loop ulnar memiliki tingkat akurasi tertinggi terhadap sensitivitas dengan nilai $1,00(0,87-1)$ dan spesifisitas $1,00(0,87-1)$, serta analisis area dibawah kurva ROC yakni $1,00(1,0-1,0)$ atau $100 \%$ dengan nilai cut off $=4$ (Tabel 3$)$.

\section{PEMBAHASAN}

Hasil penelitian berupa distribusi kemunculan pola sidik jari pada penderita sindrom Down di SLB C Negeri Tunagrahita dan anak normal di SD Negeri 14 Dauh Puri, didapatkan data yang mendukung hipotesis yang diajukan oleh peneliti yaitu terdapat perbedaan rerata frekuensi kemunculan pola dermatoglifi pada penderita sindrom Down dan anak normal.

Hasil penelitian ini seperti ditunjukan pada Tabel 2, rerata frekuensi kemunculan pola dermatoglifi tertinggi pada penderita sindrom Down adalah loop ulnar dengan besaran mean 6,39, sedangkan frekuensi kemunculan pola loop ulnar pada responden normal sebesar 2,96. Rerata frekuensi kemunculan pola dermatoglifi tertinggi pada responden normal adalah whorl dengan besaran mean 4,82, sedangkan frekuensi kemunculan pola whorl pada anak dengan sindrom Down adalah 2,25. Hasil tersebut menunjukkan terdapat perbedaan rerata frekuensi kemunculan pola dermatoglifi antara anak dengan sindrom Down dimana frekuensi kemunculan tertinggi adalah loop ulnar dibandingkan responden normal dengan frekuensi kemunculan tertinggi adalah whorl.

Hasil ini sesuai dengan penelitian lain yang pernah dilakukan, seperti penelitian oleh Sintaningtyas (2010) dengan judul Pola Dermatoglifi Tangan Pada Pasien Skizofrenia di 
Rumah Sakit Jiwa Daerah Surakarta, didapatkan kesimpulan bahwa terdapat perbedaan pola dermatoglifi pada pasien skizofrenia dibandingkan dengan responden normal pada jari II dextra, yang berarti terdapat perbedaan pola dermatoglifi antara pasien dengan kelainan genetik khususnya skizofrenia dengan responden normal. ${ }^{13}$

Hasil penelitian dalam penelitian ini mengenai perbedaan rerata frekuensi kemunculan pola dermatoglifi juga sesuai dengan teori yang telah ada, dimana gangguan pada proses kehamilan dari rentangan waktu pertengahan sampai akhir trimester sangat berkaitan terhadap perubahan atau malformasi dermatoglifi seseorang. Gangguan ini berhubungan dengan periode perkembangan otak, sehingga pola dermatogifi berkaitan terhadap kemunculan suatu retardasi mental. Variasi pola dermatoglifi yang merupakan hasil gabungan antara pengaruh genetik dan lingkungan prenatal, dapat menghasilkan perbedaan pola antara satu spesies dengan spesies lainnya. ${ }^{14}$ Variasi pola dermatoglifi dapat dipengaruhi oleh gangguan proliferasi sel epitel epidermis, tekanan pada kulit, gangguan pertumbuhan pembuluh darah perifer dan saraf perifer, kekurangan pasokan oksigen, serta gangguan proses keratinisasi saat pertumbuhan embrio. ${ }^{15}$

Secara definisi sensitivitas adalah kemampuan suatu test untuk menyatakan positif orang-orang yang sakit sedangkan spesifisitas adalah kemampuan suatu test untuk menyatakan negatif orangorang yang tidak sakit. Sebuah uji diagnostik dikatakan baik apabila memiliki nilai sensitivitas dan spesifisitas tinggi. ${ }^{16}$

Hasil penelitian mengenai tingkat sensitivitas dan spesifisitas pola dermatoglifi ditunjukan pada Tabel 3. Keempat pola utama masing-masing memiliki nilai cut off tersendiri, dengan rincian; whorl $=2$, arch $=1$, loop radial $=2$, loop ulnar $=4$. Dalam tingkat sensitivitas dan spesifisitas, pola loop ulnar memiliki akurasi tertinggi untuk mendiagnosis sindrom Down baik dari sensitivitas dan spesifisitasnya.

Hasil analisis tingkat sensitivitas dan spesifisitas pola dermatoglifi yang menyatakan pola loop ulnar memiliki akurasi tertinggi sejalan dengan hasil analisis Area Under Curve (AUC) dari Reciever Operating Characteristic (ROC). Analisis ROC adalah analisis yang digunakan untuk menilai kemampuan suatu test diagnostik yang berskala data kontinyu untuk mendeteksi adanya suatu penyakit menggunakan kurva yang disebut sebagai kurva ROC. Kemampuan pola sidik jari dalam mendiagnosis sindrom Down dikatakan baik dengan nilai Area Under Curve (AUC) $\geq 70 \%$ berdasarkan pada penelitian sebelumnya. ${ }^{13}$

Hasil uji test diagnostik pola dermatoglifi dengan parameter sensitivitas, spesifisitas, dan area dibawah curva Reciever Operating Characteristic (ROC) ini juga sesuai dengan penelitian yang dilakukan oleh penelitian sebelumnya yang meneliti pola dermatoglifi pada pasien dengan celiac disease, dimana hasil penelitiannya menunjukkan tingkat sensitivitas, spesifisitas, positif dan negatif predictive values pola dermatoglifi pada pasien dengan celiac disease masing-masing adalah 66\%, 73\%, $67 \%$, serta $71 \%$, dan diperoleh kesimpulan bahwa pola dermatoglifi tertentu secara signifikan lebih sering ditemukan pada pasien dengan celiac disease dibandingkan kontrol. ${ }^{17,18}$

\section{SIMPULAN}

Terdapat perbedaan rerata frekuensi kemunculan pola dermatoglifi, dengan frekuensi kemunculan tertinggi pada penderita sindrom Down adalah loop ulnar, sedangkan pada anak normal adalah whorl. Dalam uji diagnostik, pola loop ulnar memiliki akurasi tertinggi dalam tingkat sensitivitas dan spesifisitas sebagai penentu skrining diagnosis sindrom Down.

\section{UCAPAN TERIMA KASIH}

Terima kasih peneliti ucapkan kepada keluarga besar SD Negeri 14 Dauh Puri, SLB C Negeri Tunagrahita, dan Polresta Denpasar Sektor Kriminalitas yang telah membantu peneliti dalam proses pengumpulan data. Terima kasih juga peneliti sampaikan kepada dr. Sagung Putri Permana Lestari Murdhana Putere, M. Biomed, Sp. KJ serta pihak lain yang berperan sejak awal hingga akhir penelitian.

\section{KONFLIK KEPENTINGAN}

Tidak ada.

\section{ETIKA PENELITIAN}

Persetujuan Etik telah diterima oleh Komisi Etik, Fakultas Kedokteran dan Ilmu Kesehatan, Universitas Warmadewa, Bali, Indonesia sebelum penelitian berjalan.

\section{PENDANAAN}

Penulis bertanggung jawab terhadap pendanaan penelitian ini tanpa melibatkan pihak sponsor atau sumber pendanaan lainnya.

\section{KONTRIBUSI PENULIS}

Seluruh penulis memiliki kontribusi yang sama dalam penulisan laporan penelitian ini baik dari 
penyusunan kerangka konsep hingga interpretasi hasil penelitian dalam bentuk publikasi.

\section{DAFTAR PUSTAKA}

1. Kazemi M, Salehi M, Kheirollahi M. Down Syndrome: Current Status, Challenges and Future Perspectives. Int J Mol Cell Med. 2016;5(3):125-133.

2. Sherman SL, Allen EG, Bean LH, Freeman SB. Epidemiology of Down syndrome. Ment Retard Dev Disabil Res Rev. 2007;13(3):221-227.

3. Riset Kesehatan Dasar (RISKESDAS). Kesehatan Anak. Badan Penelitian dan Pengembangan Kesehatan Kementerian Kesehatan RI. Jakarta; 2013.

4. Montoya J, Soto J, Satizabal M, Sanches A, Garcia F. Genomic Study of The Critical Region of Chromosome 21 Associated to Down Syndrome. Colombia Medica. 2011;42(1):26-38.

5. Schnabel F, Smogavec M, Funke R, Pauli S, Burfeind P, Bartels I. Down syndrome phenotype in a boy with a mosaic microduplication of chromosome 21q22. Mol Cytogenet. 2018;11:62.

6. Seres-Santamaria A, Catala V, Cuatrecasas E, Villanueva R. Fluorescent in-situ hybridisation and Down's syndrome. Lancet. 1993;341(8859):1544.

7. Gekas J, van den Berg DG, Durand A, Valle M, Wildschut HIJ, Bujold E, Forest JC, et al. Rapid testing versus karyotyping in Down's syndrome screening: cost-effectiveness and detection of clinically significant chromosome abnormalities. Eur J Hum Genet. 2011;19(1):3-9.

8. Asen D. Secrets in fingerprints: clinical ambitions and uncertainty in dermatoglyphics. CMAJ. 2018;190(19):E597-E599.

9. Rajangam S, Janakiram S, Thomas IM. Dermatoglyphics in Down's syndrome. J Indian Med Assoc. 1995;93(1):10-13.
10. Palomaki GE, Kloza EM, Lambert-Messerlian GM, Haddow JE, Neveux LM, Ehrich M, et al. DNA sequencing of maternal plasma to detect Down syndrome: an international clinical validation study. Genet Med. 2011;13(11):913-920.

11. Masni R, Megahati R, Wati M. Dermatoglifi Ujung Jari dan Telapak Tangan Penderita Hemofilia di Sumatra Barat. Jurnal Ilmiah STKIP. 2014;(3):6-11.

12. Irawan R, Rujito L, Ferine M, Hidayat Z. Perbedaan Pola Sidik Jari Anak-Anak Sindrom Down dan Anak-Anak Normal di Purwokerto. Sains Medika. 2010;2(2):106-115.

13. Sintaningtyas LJ. Pola Dermatoglifi Tangan pada Pasien Skizofrenia di Rumah Sakit Jiwa Daerah Surakarta. Fakultas Kedokteran Universitas Sebelas Maret [Skripsi]. Surakarta; 2010:1-54.

14. Priest JH. Dermatoglyphic in Medical Disorders. Am J Hum Genet. 1977;29(4):410-411.

15. Jamison CS, Jamison PL, Meier RJ. Effect of prenatal testosterone administration on palmar dermatoglyphic intercore ridge counts of rhesus monkeys (Macaca mulatta). Am J Phys Anthropol. 1994;94(3):409-419.

16. Leeflang MMG, Allerberger F. How to: evaluate a diagnostic test. Clin Microbiol Infect. 2019;25(1):54-59.

17. Weizman Z, Vardi O, Binsztok M. Dermatoglyphic (fingerprint) patterns in celiac disease. J Pediatr Gastroenterol Nutr. 1990;10(4):451-453.

18. Makhov A, Medvedev I. Physiological and morphological peculiarities of children with Down's syndrome: A brief review. Bali Medical Journal. 2020;9(1):51-54.

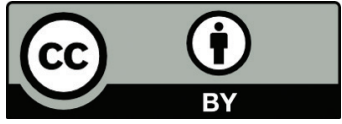

This work is licensed under a Creative Commons Attribution 